
ORCID iD: 0000-0002-3515-4187,

V. Zapototska, PhD, Assistant Professor, Y. Holub, PhD Student

Taras Shevchenko National University of Kyiv, Kyiv, Ukraine

\title{
SOCIO-ENVIRONMENTAL ASPECTS OF PROVISION OF LANDSCAPING IN THE CITY OF CHERNIHIV
}

\begin{abstract}
Chernihiv is a large city in the north of Ukraine, which has been the center of socio-cultural and political life of Ukrainians since the times of Kyivan Rus'. Today, it is an industrial and cultural center, an important transport hub. In recent years, positive changes have been observed in the socio-economic development of Chernihiv. The article reveals the main features of urban development. Its tasks and main elements are described. The situation related to the state of air pollution, water resources, including in Chernihiv, was analyzed. The main sources of environmental pollution are described. The problem of solid waste management in the city is considered. Urban noise has been described as a factor in air pollution that adversely affects human health. The effect of insolation within the city is characterized, the consequences and requirements for its consideration in the planning of cities, districts or neighborhoods are indicated. The analysis of the aeration regime of the city territory as a factor influencing the comfort of living in the city is carried out. The role of green plantations is determined, which is an important element of the natural environment and improvement of urban space. Three types of comfort in the city (ecological, social and urban) are described and their main features are pointed out. Our vision of a comfortable city, which should be compact, convenient and polycentric, to provide equal access to benefits to different segments of society, is proposed. The industrial complex and the reasons for the decline in the pace and volume of industrial production in some previously leading industries are described. The main enterprises of Chernihiv that implement modern technological solutions are identified. The transport complex of the city and tendencies of its further development are considered. An analysis of health, education, culture and recreation facilities, as well as the situation in the social sphere of Chernihiv. An analysis of a sociological survey among the city's residents on the improvement problems which concern residents the most has been carried out. This study showed that the most pressing issues for citizens are garbage removal and household waste management, the problem of heat supply and public transport. An analysis of respondents' responses revealed that they support positive trends in the creation of new sports and children's playgrounds, but want these facilities to be within walking distance of their place of residence. Most citizens are satisfied with the work of the city authorities to address the issues of improvement and comfort of Chernihiv, hoping for further positive changes. The paper identifies the priority areas of development of Chernihiv for the coming years. Among them: improving the living standards of the population, improving the environment, further economic growth, increasing employment in the city, updating and creating new quality infrastructure, supporting small and medium-sized businesses.
\end{abstract}

Keywords: city, provision of landscaping, comfort, social and ecological state, industrial complex, urban development.

Introduction. The city is the leading form of territorial and socio-economic organization of our society. Urban development inevitably contributes to the transformation of almost all components of the environment. The greatest impact of urbanization processes is felt on the quality of atmospheric air, natural waters, soil conditions and increasing the amount of household waste. At the same time, negative changes in the environmental situation lead to a deterioration in the quality of life of the population, affecting many aspects of their lives. Population growth, the deepening of their impact on the environment and the scientific and technological revolution have led to the emergence of new complex challenges related to the normal development of cities. Among them: accelerating urbanization, environmental pollution, changing the structure of the city's economy, complicating infrastructure, increasing resources and costs to meet the needs of the population, a large number of potential threats and more.

Literature review.Ukrainian and foreign scientists have been studying the socio-economic development of the city and the state of the ecological situation in the urban settlement. Thorough research of Ukrainian geographers on urban development is covered in the works of O. V. Berdanova "Planning of socio-economic development of the city" [3], O. V. Boyko-Boychuk "World trends in urban development: international experience" [4], I. G. Grechanovska "Urban areas as an object of nature" [5], O. L. Dronova "Geourbanistics" [7], O. I. Kary "City space as an important factor in its socio-economic development" [12], B. S. Posatsky "Fundamentals of Urbanism. Territorial and spatial planning "[21], N. S. Sosnova "Transformation of the urban environment as a reflection of economic and social processes in the largest cities of Ukraine" [27] and others. Theoretical aspects of the development of urban settlements are covered in the works of foreign scientists:
Berry B. Cities as systems within systems of cities [31], Harris C.D. The nature of cities [33], Jensen-Butler C. Competition between cities, urban performance and the role of urban policy: a theoretical framework [34], Park R. The City as a Social Laboratory [36], Taylor P. J. Cities in Globalization: Practices, Policies and Theories [37].

Landscaping of urban areas as a socio-geographical category is reflected in the following works: Al-Fahad A.Z.M. "Environmental problems of sustainable development and improvement of urban areas and ways to solve them" [1], Bezlyubchenko O. S. "Planning and improvement of cities" [2], Ksenevich M. Y. "Urban foundations of sustainable development of the city of Kiev" [13], Ugryumova A. A. "Comfort as a factor in sustainable development of the urban environment" [30].

Chernihiv is the administrative, industrial, economic and cultural-educational center of the Chernihiv region. The city, the first mention of which dates back to 907, according to the Law of Ukraine "On Protection of Cultural Heritage" is classified as a historic city [23]. According to the Main Department of Statistics in the Chernihiv region, the population of Chernihiv on December 1, 2019 amounted to 287.1 thousand people [14].

In recent years, the city authorities have been taking measures aimed at maintaining and continuing the positive trends in the socio-economic development of the city. Priority areas remain improving living standards and sustainable development, which include economic growth, creating new jobs to increase employment, supporting small and medium enterprises, upgrading and creating new quality social and engineering and transport infrastructure, improving the environment and increasing space of green areas.

Urban area is characterized by higher air temperature than in rural areas, the intensity of electromagnetic radiation, background noise. Excessive levels of nitrogen dioxide and 
sulfur, carbon monoxide, phenol, and hydrogen cyanide cause air pollution in the area affected by industrial facilities and urban transportation. This has a negative impact on human health, especially on diseases of the respiratory system, cancer, birth defects and cardiovascular system, as well as vegetation, wildlife, architectural structures and historical monuments [2].

The Law of Ukraine "On Landscaping of Settlements" provides the following definition of landscaping: "Complex landscaping is a complex of works on arrangement (restoration) of covering of roads and sidewalks, equipment with devices for traffic safety, landscaping, provision of external lighting in a certain territory of the settlement (microdistrict, quarter, park, boulevard, street, lane, descent, etc.) and outdoor advertising, the installation of small architectural forms, the implementation of other measures aimed at improving the engineering and sanitary condition of the territory, improving its aesthetic appearance [9]. In our opinion, from the standpoint of human geography, the following definition is the most correct: landscaping of the city is a set of measures aimed at creating comfortable and safe living conditions, normal operation of industrial facilities, transport, and to improve attractiveness and aesthetics urban space in compliance with all standards of labor protection and ecology.

The main task of urban development is to improve the quality of life and preserve the environment. Elements of landscaping are defined:

- coverage of squares, streets and roads, sidewalks, other zones and paths in accordance with current legislation;

- greenery along the streets, in parks and squares, public places, sanitary protection zones, etc .;

- institutions and structures engaged in waste collection and disposal;

- means of outdoor lighting and advertising;

- technical means of traffic regulation (road signs, traffic lights, boards);

- objects of the system of engineering protection of the territory;

- buildings and complexes of monumental art, fountains and decorative pools;

- equipment on children's and sports grounds;

- small architectural forms (arcades, benches, bridges, fences), etc. [9].

Ecological improvement of territories plays an important role for the development and functioning of the modern city. It provides a system of measures that ensure the protection of components of nature and the creation of the necessary conditions for environmental safety of the city's population. The main role in preserving the environment is played by national measures, which provide for the rational allocation of productive forces, restrain the expansion of settlements, address issues of air pollution, water resources, soils, flora. All these measures can be included in the system of urban development, because the city is considered comfortable and sustainable in its development, where clean air, many green areas, no large landfills, no polluted water bodies.

Atmospheric air pollution. The main sources of air pollution are energy, metallurgy, transport, industrial and municipal waste, others anthropogenic factors. Natural factors are added to them: fires, dust, volcanic eruptions, etc. Regarding the state of the atmosphere in cities, the level and degree of pollution are determined by the size of the city, the development of the economic complex, population, number of cars, natural conditions of the urban area.

According to the Main Department of Statistics in Chernihiv region [14], the amount of pollutant emissions into the atmosphere from stationary sources of pollution in Chernihiv maintains a general downward trend. Analysis of statistical information on emissions from mobile sources shows a similar situation. The largest anthropogenic load on the air within the city is made by Chernihiv TPS, which is included in the "TOP-100 major polluting enterprises". In total, the share of its emissions is $85 \%$ [29].

Monitoring of air pollution in the city is carried out at two posts. The content of 4 main impurities is monitored: suspended solids, sulfur dioxide and nitrogen, carbon monoxide and heavy metals. Each month about 600 air samples are taken for the content of the above substances and analyzed by the laboratories of the Central Geophysical Observatory. In the last few months of the end of 2019 , the average daily maximum concentration of nitrogen dioxide was exceeded. The average monthly concentrations of sulfur dioxide, carbon monoxide and other impurities were normal and did not exceed the maximum allowable concentrations [28]

The problem of water pollution. The country's water resources are the main source of drinking water for the population. One of the properties of water is the ability to self-clean, but there is a limit to everything. The intensification of urbanization processes, the growth of humanity on the planet, the rapid development of production require an increase in water use. The state of water resources of the city depends on the number of inhabitants, building area, the availability of water bodies. The main sources of pollution include industrial wastewater, domestic sewage, waste from livestock complexes, water from mines and quarries, discharge of water and rail transport, thermal pollution and more.

The main objects of the hydrographic network of Chernihiv are the rivers Desna, Strizhen and Belous. Pollution of these rivers within the city occurs due to the removal of pollutants from stormwater. Due to the lack of a modern storm sewer network in Chernihiv, almost $95 \%$ of precipitation falls into the city's rivers without prior treatment. The biggest polluter of water bodies in Chernihiv is the Chernihivvodokanal utility company. According to the results of recent observations, the maximum permissible concentrations of some chemicals (iron, suspended solids, nitrites) in some sections of rivers have been recorded [28].

Household waste management. Garbage is one of the main problems of cities in Ukraine. Every year, Ukrainians produce about 11-13 million tons of solid waste, almost everything is buried in landfills, and only $3-5 \%$ is recycled. At the same time, in the countries of the European Union the level of solid waste processing is $60 \%$. The vast majority of landfills are overloaded, they work in violation of the indicators of waste accumulation. At the same time, landfills are dangerous for the environment because they are a source of air and groundwater pollution. The issue of establishing new landfills and waste processing plants near cities is difficult. Half of the landfills accept industrial waste. In addition, for many cities the problem of creating unauthorized landfills is relevant [25].

The share of household waste in the overall structure of waste in Ukraine is insignificant - only $2-3 \%$, but the effective functioning of this part of the economy is important because of the direct impact on the environment of any settlement, especially large cities. The problem of garbage accumulation negatively affects the general sanitary condition of the city, the aesthetic appearance of streets, parks, public transport stops, etc. This creates conditions for the comfort of life of the population, affects their desire to live and work in such an urban space.

The problem of waste accumulation and processing is one of the most acute for the city of Chernihiv. Annually, the city generates about 135 thousand tons of waste, per person - about $300 \mathrm{~kg}$ [14]. Currently, Chernihiv has a unitary 
system of solid waste collection, which does not allow to remove the necessary waste that has resource value or hazardous substances.

The construction of a waste processing plant has been planned for several years, as the landfill where garbage is transported has been operating since 1961 and has been reloaded. Its operation was supposed to end in 1997, but it continues to operate due to the lack of any alternatives. This is a real ecological catastrophe for the inhabitants of the surrounding areas, fires often occur in summer, and the characteristic smell of the landfill spreads to the surrounding areas [8].

Environmental behavior of urban residents should be based on the principles of waste sorting - the first step towards waste management. The reason for such actions should be the understanding of people that it will reduce the negative impact on the environment and improve the quality of their lives in the city. Unfortunately, the majority of the population is characterized by an insufficient level of environmental education, which leads to a low level of implementation of waste sorting [10].

City noise. One of the factors that contributes to air pollution and negatively affects human health is the increased noise level in the city. It adversely affects the lives of citizens. In the case of prolonged exposure to noise, they gradually increase irritability and disturbed sleep, reduced productivity. Constant noise exposure causes stress, which in turn can cause high blood pressure, heart rate, increased levels of lipids in the blood. This can lead to cardiovascular disease. Particularly negative is the impact of noise on children, who then have reduced memory, concentration and success [32, 35].

Land road and rail transport is the main source of intense and prolonged noise. Their share is $80-90 \%$ of the street noise level. Its action extends beyond the roadway and penetrates into residential areas, in places where people live. The noise level depends on several transport characteristics. Among them: speed, percentage of freight and public transport, power and mode of operation of engines, the quality of the road surface. Most often, traffic noise in cities exceeds the permissible values by 25-35 dB, which requires specific measures [2]. The absence of large industrial facilities and an airport in Chernihiv contributes to a slight excess of noise. The main residential areas are located relatively far from the main streets with active traffic and industrial enterprises, which may affect the performance.

Insolation within the city. Insolation is the illumination by sunlight of various buildings and architectural structures; the combination of thermal and light action of the sun. By heating and illuminating the territory, buildings and structures, the sun's rays affect the microclimate, the quality of the environment, the hygiene of the premises, the expressiveness and condition of architectural complexes.

The most important negative effect of insolation is its detrimental effect on human health. Ultraviolet radiation from the sun leads to accelerated skin pigmentation, the formation of pigment spots and moles. Excessive radiation can cause melanoma and non-melanoma malignancies of the skin, cataracts and other eye diseases. Large doses of ultraviolet radiation cause burns, loss of elasticity and resilience of the skin, and as a consequence of accelerating its aging. Taking this lack of insolation into account is important when designing schools, universities and other educational institutions.

When planning cities, districts or neighborhoods, it is necessary to take into account the conditions of insolation, taking into account the sides of the horizon, the orientation of the streets, the configuration and location of buildings. In addition, this is taken into account when selecting plants for landscaping. Uncomfortable zones and comfort zones with a light level of more than 3 hours a day are determined. The formation of the planning structure of a particular residential complex in these areas and changes in the insolation regime can cause difficulties. This is due to the established location and orientation of existing buildings, the change of parameters of which will require significant adjustments and demolition. It is important to ensure the correct conditions of insolation in such cases, because direct sunlight is a means of self-cleaning space [2].

Aeration regime of territories. Aeration of the city involves a natural process of ventilation of its territory. Transformation of air flow in its interaction with natural and anthropogenic landscapes, man-made objects is an integral process. These changes both the speed and direction of the wind. All these factors will affect the aeration regime of the city. Therefore, for the effective functioning of the settlement at the stage of planning and design it is necessary to thoroughly study the processes of aeration of the urban area

The increase in building density, which is associated with the active growth of the modern city, is the reason for the deterioration of ventilation in residential areas. If the city performs industrial functions, then there is also the problem of air pollution of the surrounding areas, which is due to the obstruction of effective ventilation. These factors significantly affect the microclimate of urban space, in particular, the aeration and insolation regimes [26].

Taking into account the aeration regime of residential buildings in large cities, where transport and industrial production are active, is important for improving the sanitary and hygienic living conditions of the population. Ensuring wind comfort is one of the main tasks at the design stage and during the architectural and climatic analysis of the territory. After all, the speed and direction of the wind can affect the direction of the streets, the location of functional areas, industrial enterprises in relation to residential areas, recreation areas, etc. [2].

Greenery. Vegetation within the city is an important element of the natural environment as well as cultural heritage. The development and implementation of master plans is carried out in compliance with the requirements for the protection of greenery and ensuring their optimal number in relation to the area of the city or a particular area. Any urban planning activities must be carried out in compliance with all necessary norms for the protection of green areas.

The most negative impact on vegetation within the city are the following factors: the impact of urban space (heavy load on parks and squares), pollution of the atmosphere and soil, recreational load (trampling, physical destruction, improper traffic).

Over the past 5 years, there have been significant changes in the reconstruction of city parks and recreation areas. Bohdan Khmelnitsky Square, located in the historic part of the city, was renovated in 2017. During one year of repair works, the hard surface and cable network were completely changed, three new fountains were created, the number of park benches was increased, the park was fenced off from the neighboring streets, and children's bicycle paths were built.

In the same year, a project for the reconstruction of the Alley of Heroes [20] was presented - a connecting park area between the historic district (Val) and the administrative center. In 2018, the park was renovated. The main idea of the project was to create a space for the most comfortable recreation for people. The architects and managers of the city sought to get rid of post-soviet elements, to approach European principles in planning and use of the territory. Paving of the Alley was carried out with multi-colored 
cobblestones, the manufacturer of which is a Chernihiv company. Instead of 4 former rectangular, now the park has 3 round fountains, the size of which decreases to the periphery. The green area is represented by trees, lawns and flower beds planted in the form of ribbons.

Comfort of urban space. Summarizing the above factors that affect the ecological improvement of the urban area, we can talk about the comfort of the city. The formation of a comfortable urban space is a natural process of development of the city at a qualitatively new level, because it creates conditions for improving socio-economic indicators and quality of life. The comfort of the urban environment includes several components, including: economic and social spheres, housing, health care, education, production processes, pensions and insurance.

The comfort of the city is a subjective feeling, which is manifested in the state of human health, his emotional satisfaction, perception of the environment in which he is. This is reflected in the comfort of visual and sound space, the presence of aromas that have a positive effect on well-being and health. The harmonization of the city space presupposes the domination of the center and peripheral districts, streets and avenues, the establishment and improvement of transport and social infrastructure, etc. In this case, the urban landscape should be in harmony with the environment and ecosystem of the city [30].

Given the factors shaping the urban space, there are three types of comfort in the city:

1. Ecological comfort - includes the advantage of geographical location, the absence of environmentally dirty and hazardous industries, chemical and nuclear waste, the presence of green areas, as well as conditions for the safety of life, due to the absence of adverse natural processes and phenomena.

2. Social comfort - covers security (absence of hostilities or acts of terrorism, general criminal situation), opportunity to get a good education, employment and income level, quality of life, availability of necessary social infrastructure to meet the needs of residents, environment (nationality people, cultural level, age, traditions).

3. Urban comfort - involves the availability of their own housing and its quality, a good level of public transport, communications, favorable urban space for living (appearance of the city, cleanliness, comfort), the formation of a positive emotional state and satisfaction of city residents [30].

In our opinion, a comfortable city should be compact, convenient and polycentric, provide equal access to benefits for different segments of society. City residents should take part in the development of the city, express their wishes and requests for the functioning of its individual areas, which will then be taken into account by professionals in the implementation of plans. The identity of the city is important. It cannot be disturbed during reconstruction: to destroy historical monuments, to damage facades, to build monotonous glass business centers. Such solutions can lead to the emergence of identical cities that do not have the features of uniqueness.

More than 2,8 thousand enterprises operate in Chernihiv, which is $47,5 \%$ of the total number of enterprises in the Chernihiv region, about 400 of them produce industrial products. Industry plays an important role in the life and employment of the population of Chernihiv and accounts for a share in the real sector of the economy. Most companies work in the food and light industries, mechanical engineering, installation and repair of machinery and equipment, construction materials, pulp and paper and printing, as well as the chemical industry. The main enterprises of the city are KSK "Cheksil", JSC "Chernihiv garment factory "Elegant",
Chernihiv Plant of radio equipment (CHEZARA), LLC "SIVERTEX" and others (fig. 1) [29].

However, over the past 10 years, there have been losses in the city's industrial sector. From 2011 to 2014, the production of PJSC "Metalist", PJSC "Chernihiv Chemical Fiber", PJSC "Metiz" and PJSC "Chernihiv Meat Plant" was suspended [28]. The production ties of Chernihiv enterprises became more complicated and significantly reduced (mainly with the enterprises of the former Soviet Union) after the proclamation of Independence. The machine-building complex of Chernihiv underwent the greatest changes. Previously, it focused on Russia's needs in creating joint products for the automotive industry and the military-industrial complex. Re-profiling and reorientation of enterprises to create new products that would be in demand and meet market needs takes a long time. Changes in the city's engineering are much slower than in other industries, which is the reason for the loss of previous positions.

Lightindustryhasalways occupied one of the leading positions in the production sector of the economy of Chernihiv. Currently, it is among the top three in terms of the share of products and exports. However, over the past few years, the pace of production of the industry is growing slowly. The reason for this can be considered very low demand in the domestic market due to lack of consumer awareness of product quality and the availability of cheaper counterparts from competing manufacturers. The market of most cities of Ukraine is filled with garments and footwear of foreign production, which are affordable for Ukrainians. However, the growing trends of support for the national producer, who creates modern and high-quality products, creates additional conditions for the development of light industry [29].

An important reason for the decline in the overall pace and volume of industrial production over the past 5 years was the violation of relations with the aggressor country of the Russian Federation. Many companies have lost production ties or the conditions of their joint activities with foreign partners have become significantly more difficult. In addition, a significant decline in production is due to outdated equipment and production facilities that operated 30-40 years ago. Significant factors hindering development are also the lack of domestic demand, a sharp devaluation of the national currency and rising prices for energy and raw materials [29].

About $70 \%$ of foreign direct investment is directed to the industrial sector of the city. There are industrial enterprises in Chernihiv that distribute modern technological solutions with exclusively foreign capital. These are, for example, Novofil LLC, Plast-Box Ukraine LLC and Kabel Ukraine TF LLC.

"Novofil" specializes in spinning silk, artificial and synthetic fibers. This is the only enterprise in Ukraine that uses the technology of braiding elastomeric thread. The production is environmentally friendly, the most modern energy-saving equipment works, and the products are in demand not only in our country, but also abroad. The main investor is Italy [29]. Plast-Box Ukraine LLC is a manufacturer of plastic containers and packaging. The main company is Plast-Box SA, which is considered one of the leading Polish companies. The company's products are used in many sectors of the economy. These are containers for the food industry, packaging for the chemical industry, boxes for transportation and storage of products. "Plast-Box Ukraine" uses the best innovative high-tech equipment and IML technology (soldering in the products of labels at the time of their production) [16]. 


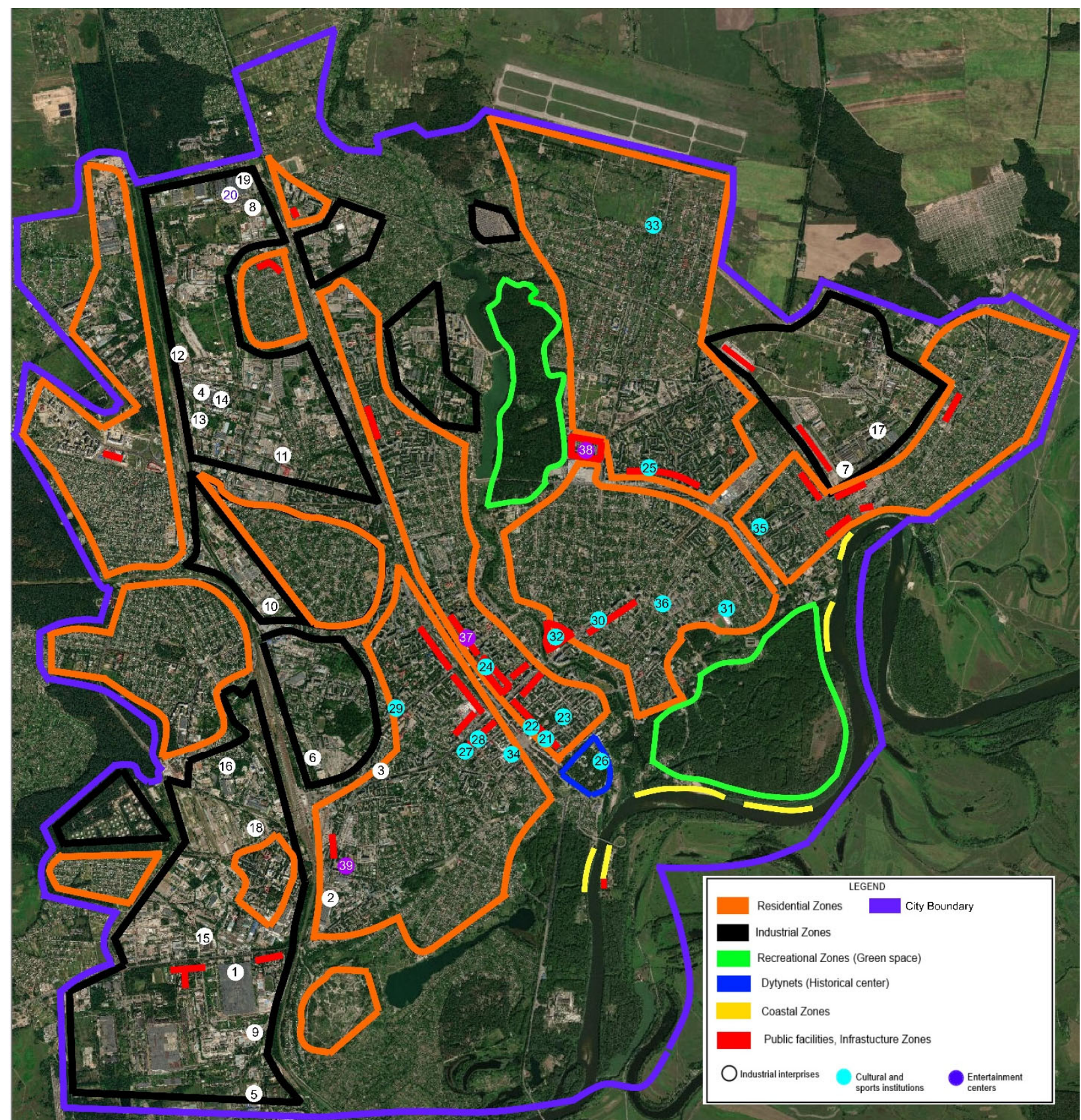

1. KSK "Cheksil"

3. JSC "Chernihiv garment factory "Elegant"

4. LLC CHERNIHIV FORGING PLANT

5. Chernihivpowerplants

6. UC CHERNIHIVVODOKANAL

7. Chernihiv Plant of radio equipment (CHEZARA)

8. CHERNIHIV MECHANICAL PLANT (PRJSC CHMP)

9. Plast-BoxUkraine

10. Mainpac

11. ALC "YASEN"

12. PrJSC "Mlybor"

13. Anheuser-BuschlnBevUkraine

14. MalteuropUkraine

15. PC ROSTBUD

16. Chernihiv Brick Plant №3, Close Joint-Stock Company

17. LLC "SIVERTEX"

18. PrJSC"Plant of metal structures and metal equipment"

19. LLC "ChernihivAutomotivePlant"

20. LTD "Ukrainian Cardan"

21. Chernihiv Regional Philharmonic Center of festivals and concert programs

22. Taras Shevchenko Chernihiv Regional Academic Music and Drama Theatre

23. ChernihivTheatre for Youth
24. Korolenko Chernihiv Regional Universal Scientific Library 25. ChernihivRegionalLibraryforChildren

26. Tarnovskyi ChernihivRegionalHistoricalMuseum

27. Chernihiv literary-memorial museum-reserve of Kotsyubinsky

28. Central City Library for children of Dovzhenko

29. City Palace of Culture named after VyacheslavRadchenko

30. ChernihivPalaceofCultureofchildrenandYouth

31. Children's Youth Sports School "Athletics"

32. Children's Youth Sports School "Chernihiv"

33. Children's Youth Sports School of Olympic reserve

34. Children's Youth Sports School "Ukraine"

35. Children's Youth Sports School "Fortuna"

36. Regional Children's Youth Sports School "Olimp"

37. TSUMChernihiv

38. SEC Hollywood

39. SEC Royal 
TF "Cable Ukraine" - an enterprise for the production of cable and wire products. After its inclusion in the structure of "TELE-FONIKA Kable" and investment, the number of jobs increased, new production equipment was installed and modern technologies were mastered. This company has developed a quality management system in accordance with ISO 9001-2000, as well as an environmental protection system in accordance with ISO 14001: 2004. At present, the company's products have a high reputation due to its quality. Constant research and new developments, as well as modern equipment and materials used contribute to this [15].

According to the rating agency "Credit Rating", which analyzes the economic indicators of urban development and prospects for the future, in 2019 Chernihiv increased its position and "is characterized by a high level of attractiveness for investment" [6].

Improving energy efficiency is one of the main directions of the city's development. In Chernihiv, the Sustainable Energy Action Plan for 2015-2023 (SEAP) was approved. It was previously determined that the implementation of such measures will help reduce the use of gas by 56,8 million $\mathrm{m}^{3}$, energy by 1,023 million MWh and reduce $\mathrm{CO} 2$ emissions to 297 thousand tons per year (23\% of the base year 2008). This plan is implemented in the field of heat and water supply, public transport, residential and office buildings, lighting [18].

As part of the implementation of the Energy Efficiency Improvement Program in budget institutions of Chernihiv for 2017-2027, measures to replace windows and fill door blocks in educational institutions are envisaged. The cooperation of the city authorities with the GIZ Projects has facilitated the implementation of energy efficiency programs for the city's public sector. For example, equipping the building of the city hospital № 1 with a separate heating system (heat savings is $17 \%$ ), reconstruction of the first building of the college № 11 (installation of energy-saving windows and doors, wall insulation, basement ceiling). The renovation allowed to reduce heat consumption by the educational institution by $35 \%$ [29].

According to the results of the first half of 2019, energy consumption decreased by $6,1 \%$ compared to the previous year. Such budget savings amounted to approximately UAH 5 million [6].

The transport complex of the city is represented by urban electric and road transport. Within Chernihiv there are three bus stations, two railway stations and a river port. The city has an extensive road system, the total length of streets is $361 \mathrm{~km}$. However, more than $24 \%$ of Chernihiv's roads are in critical condition [29]. Currently, Chernihiv is characterized by a public transport network, which includes 36 bus and 10 trolleybus routes. The model of passenger transportation, which has developed in recent years in the city, does not satisfy the population. There is almost no renewal of vehicle rolling stock. Expansion of existing city boundaries and construction of new neighborhoods make changes to the route network of Chernihiv [11].

In March 2019, the City Council approved the Rules for the use of urban passenger road transport in Chernihiv. The main goal was to improve the quality and efficiency of services in the introduction of an automated fare system [21]. The city is studying the demand of the population for different types of transport and directions of movement. The aim of such measures is to avoid duplication of bus and trolleybus routes, as well as to maintain healthy competition between 14 carriers. 36 stops are equipped with electronic boards showing the time of arrival of public transport. They are connected to the Dozor monitoring system, which constantly monitors the operation of vehicles with the help of video surveillance cameras and GPS trackers installed in the rolling stock of buses and trolleybuses [24].

Development of human potential "Man is above all" is one of the strategic goals of the City Development Strategy. Its components are the creation of the necessary conditions for the provision of quality medical care, the promotion of a healthy lifestyle and the receipt of quality education by the population.

The critical situation in Chernihiv is related to the state of health of the population: there is a high level of morbidity, disability and mortality among the citizens. In the last few years, the mortality rate has remained at $11.5-12.5 \%$, the birth rate is 8,5-9\%o. In addition, the city is aging. However, this is not due to an increase in life expectancy in older age groups, but a decrease in fertility.

Medical care in the city is provided by four city hospitals, two children's clinics and two dental clinics, a maternity hospital. In 2019, repairs were carried out in hospitals and clinics, four cars were purchased for health care facilities in Chernihiv, computer equipment and equipment, a monitoring system and dental units worth UAH 2.8 million were purchased [6]. Providing hospitals with staff remains a health issue. This is due to low wages, unattractiveness of the region in terms of economic development and environmental situation [29].

Chernihiv has an extensive system of preschool and secondary schools. According to the Department of Education of the Chernihiv City Council [19], there are 53 kindergartens, 34 secondary schools, an evening school, 2 children's sports schools and a center for tourism, health and educational work with children. However, in some areas kindergartens are overcrowded. An example is the Masana neighborhood, where young families live and new housing estates are constantly being built. In Chernihiv, attention is paid to children with physical disabilities, so 36 classes with an inclusive form of education have been created in 9 institutions of the city. Every year the number of inclusive classes and groups increases.

Institutions of vocational and technical (5 in total) and higher education (2 universities) have different areas of training and contribute to a high professional level of specialists. According to the rating (Education UA) in 2019, Chernihiv National University of Technology took second place (in the overall ranking 51-52), behind the Sumy State University in the northern region [17]. However, the city is characterized by an imbalance: a sufficient number of young educated people see a completely different level of wages and are not ready to find jobs in available vacancies.

Regarding the development of culture and recreation, the city has a developed network of institutions that contributes to the spiritual development of Chernihiv. The sphere of culture includes 20 institutions (academic music and drama theater, palaces of culture, libraries, schools of aesthetic education, museums, puppet theater), which 8 of them are subordinated to the Department of Culture and Tourism. The activities of such institutions are aimed at meeting the cultural needs of the population of all ages, further development of the spiritual sphere and the growth of its role in the life of citizens, ensuring the preservation of cultural heritage.

Every year more and more people join sports. The city promotes not only the involvement of young people in physical culture and health activities, but also the working population. Every year there are competitions among civil servants and local government employees, ski races, table tennis, beach volleyball, football and basketball. Athletes' victories at international competitions encourage young people to practice and promote sports. However, such hobbies of the population require investment in the development of sports infrastructure: construction of new 
sports complexes and modernization of existing buildings, existing equipment and inventory. Thus, during 2018-2019 the stadium "Youth" was re-equipped, the sports grounds of educational institutions were reconstructed: schools № 1 , $12,13,35$, and the construction of a modern stadium "Chernihiv Arena" continues [6].

To ensure sustainable economic and social development of the city of Chernihiv, increase its competitiveness and human development, the Strategy of Chernihiv City Development until 2020 was approved [29]. Strategic goal № 2 "Development of housing and communal services and infrastructure of Chernihiv. "Comfortable city" includes the operational goal "Balanced urban development". Its main tasks are

- development of public space within the city;

- development of a plan for the management of spatial resources of the city with the priority of forming a compact structure of urban areas;

- unification of the urban environment: development of the design code of the city, management programs for outdoor advertising;

- increasing the level of public safety;

- preservation and increase of architectural, cultural and natural values of Chernihiv.

The next operational goal is the ecological development of the city, which includes the development of key infrastructure for the safe development of the city environment. Among its tasks are:

- construction of a waste processing plant;

- monitoring of the state of the environment (level of air, soil, surface water pollution, radiation control);

- modernization and construction of a new network of water supply and sewerage systems;

- upgrade of the rainwater drainage system to reduce water pollution [29].

Strategic goal № 3 Human development "Man - above all" includes 4 operational goals. The first of them, "Creating conditions for the provision of effective, affordable and quality medical care ("Healthy City")" Healthy City "includes:

- availability of first aid and improving the quality of services (purchase of modern equipment, vehicles, repair of medical buildings, attracting highly qualified personnel to work in the city, advanced training of medical workers);
- improving the quality and availability of secondary medical care (improving the medical care system, developing the diagnostic and treatment base, improving the quality of medical services);

- prevention and early detection of dangerous diseases;

The second goal of "Promotion of a healthy lifestyle" involves educational work and promotion of a healthy lifestyle, development of sports infrastructure and renewal of the existing material and technical base of sports schools and complexes, creating conditions for involving people with disabilities in physical culture.

The third operational goal is to provide conditions for quality education ("Intelligence of citizens $=$ city development"). Its most important tasks are

- improving the quality of education in the city (improving the skills of employees of educational institutions, creating conditions for the competitiveness of institutions, the use of information technology in the learning process, the transition of educational institutions to alternative heating, mobility of pupils, students in international cooperation to acquire new knowledge and skills during the exchange);

- construction of a new school and kindergarten in the Masana district;

- building a network of preschool institutions and involving more children in preschool education (improving the skills of educators, optimizing the level of occupancy of groups and opening additional groups, repairing buildings, replacing windows and insulation);

- training according to the needs of the labor market [29].

As part of the sociological study, a survey was conducted among the residents of Chernihiv on the problems of landscaping that concern them the most. The field stage of information collection took place in the period from May 11 to June 11, 2020 in 2 districts of the city: Desniansky and Novozavodsky. Research audience: the population of Chernihiv aged 18 and older. As a result of the work performed, 150 people were interviewed. The method of gathering information is a personal formalized interview at the place of residence of citizens. The distribution of respondents by sex and age is presented in Table 1.

Table 1. Distribution of respondents by sex and age

\begin{tabular}{|c|c|c|}
\hline \multirow{2}{*}{ Representativeness criterion } & \multicolumn{2}{|c|}{ Share } \\
\cline { 2 - 3 } & Number & \% \\
\hline Males & 68 & 45,3 \\
\hline Females & 82 & 54,7 \\
\hline
\end{tabular}

\begin{tabular}{|c|c|c|}
\hline \multirow{2}{*}{ Representativeness criterion (age) } & \multicolumn{2}{|c|}{ Share } \\
\cline { 2 - 3 } & Number & \% \\
\hline $18-30$ & 37 & 24,7 \\
\hline $31-50$ & 61 & 40,7 \\
\hline $50+$ & 52 & 34,6 \\
\hline
\end{tabular}

According to the obtained data (Table 2), among the problems of landscaping that concerned the respondents the most were such as garbage removal and household waste management, transport, arrangement of playgrounds and sports fields, as well as bicycle paths. In terms of 2 districts, there were some, albeit minor, differences in terms of priority issues. Residents of Desnianskyi district were more concerned about the removal of garbage and household waste management, repair of the water supply system, and construction of playgrounds. The most important for the residents of Novozavodsky district were the arrangement of children's and sports grounds, the work of public transport, as well as the problem of household waste management. Regarding the age differences, the respondents of the younger age category were concerned about the removal of garbage and the arrangement of playgrounds and bike paths, while the older group stressed the problems of heat supply and public transport. 
Table 2. Distribution of answers of respondents by age to the question

"What do you think, what landscaping problemsof your district should be solved first of all?", $\%$ of the total number of responses for each district

\begin{tabular}{|c|c|c|c|c|c|c|}
\hline \multirow{3}{*}{ Landscaping problems } & \multicolumn{6}{|c|}{ District/Age } \\
\hline & \multicolumn{3}{|c|}{ Desnyans'kyy } & \multicolumn{3}{|c|}{ Novozavods'kyy } \\
\hline & $18-30$ & $31-50$ & $50+$ & $18-30$ & $31-50$ & $50+$ \\
\hline repair of water supply system & 4,7 & 14,2 & 16,6 & 4,5 & 5,7 & 5,7 \\
\hline garbage removal, household waste management & 25,3 & 20,6 & 26,9 & 12,6 & 11,4 & 10,3 \\
\hline power supply & 4,7 & 6,3 & 9,5 & 3,4 & 2,3 & 2,3 \\
\hline heat supply & 3,1 & 7,9 & 9,5 & 5,7 & 8,1 & 9,1 \\
\hline street lighting & 3,1 & 9,5 & 7,9 & 2,3 & 3,4 & 5,7 \\
\hline condition of the sewer system & 3,1 & 4,7 & 4,7 & 2,3 & 1,1 & 2,3 \\
\hline street cleaning & 1,5 & 3,1 & 3,1 & 2,3 & 3,4 & 3,4 \\
\hline arrangement of sports grounds & 12,6 & 14,2 & 6,3 & 17,2 & 12,6 & 4,6 \\
\hline arrangement of playgrounds & 7,9 & 26,9 & 19,1 & 10,3 & 12,6 & 5,7 \\
\hline availability of parking spaces & 6,3 & 14,2 & 7,9 & 5,7 & 9,1 & 3,4 \\
\hline creation of green zones & 1,5 & 1,5 & 3,1 & 1,1 & 1,1 & 2,3 \\
\hline arrangement of bicycle paths & 22,2 & 20,6 & 9,5 & 9,1 & 8,1 & 8,1 \\
\hline public transport & 3,1 & 7,9 & 15,8 & 4,6 & 13,7 & 20,6 \\
\hline
\end{tabular}

According to the majority of respondents, the city authorities are taking certain measures to improve the city's amenities (Table 3). Survey participants noted that the situation in Chernihiv has improved significantly recently: roads are being repaired, a large number of parks and squares have been created, a beach on the Desna River within the city limits has been arranged, and public transport stops are being renovated.

Table 3. Distribution of respondents by age to the question

"How do you assess the policy of the city authorities in ensuring the improvement of your district and the city in general?" $\%$ of the total number of responses for each district

\begin{tabular}{|c|c|c|c|c|c|c|}
\hline \multirow{3}{*}{ Evaluation of government policy } & \multicolumn{6}{|c|}{ District/Age } \\
\hline & \multicolumn{3}{|c|}{ Desnyans'kyy } & \multicolumn{3}{|c|}{ Novozavods'kyy } \\
\hline & $18-30$ & $31-50$ & $50+$ & $18-30$ & $31-50$ & $50+$ \\
\hline $\begin{array}{c}\text { The city authorities are taking certain measures and the state } \\
\text { of landscaping is improving }\end{array}$ & 12,6 & 22,2 & 9,5 & 5,7 & 20,6 & 10,3 \\
\hline The city authorities do not carry out effective work & 6,3 & 7,9 & 6,3 & 4,5 & 5,7 & 3,4 \\
\hline $\begin{array}{l}\text { The situation is deteriorating and the authorities } \\
\text { are not responding }\end{array}$ & 1,5 & 0 & 1,5 & 1,1 & 1,1 & 2,3 \\
\hline Difficult to answer & 4,7 & 6,3 & 3,1 & 3,4 & 4,5 & 3,4 \\
\hline
\end{tabular}

The priority directions of Chernihiv development for the coming years are:

- promoting the creation of conditions for the construction and development of new enterprises, modernization of existing industries;

- establishing a partnership in the direction of "business - city government";

- attracting investments and international experience for the implementation of infrastructure projects;

- ensuring the comprehensive development of education;

- ensuring social protection of city residents;

- promotion of a healthy lifestyle, free access of citizens to quality medical services;

- preservation and development of architectural and cultural monuments of the city and natural values [29].

Conclusions. The city is one of the most complex manmade systems. It is the main center of economic, political, cultural and social processes that are currently taking place in the world. Chernihiv is a large city in the north of Ukraine, which has been the center of socio-cultural and political life of Ukrainians since the times of Kievan Rus. Today, it is an industrial and cultural center, an important transport hub, which is home to 287,1 thousand people. In recent years, positive changes have been observed in the socio-economic development of Chernihiv. In particular, it is manifested in the growth of capital investment, repair of the road surface of many streets and sidewalks of the city, arrangement of "smart stops" on public transport routes, reconstruction of underground passages in the central part of the city, repair of health facilities, re-equipment of stadiums and creation of new sports and children's playgrounds. In addition, the city authorities have done a lot of work on the arrangement of green areas, parks and squares, as well as the central square of the city. Chernihiv has become much more comfortable to live in, and the citizens feel it. A sociological survey on landscaping conducted in the city confirmed the existing trends. Chernihiv residents are generally satisfied with the work of the city administration, but pointed out some problems. Among them: the work of public transport and the renewal of rolling stock, the issue of garbage removal and household waste management, as well as the creation of more playgrounds and sports grounds for the accessibility of all interested residents of the city.

\section{References}

1. Al'-FakhadA. Z. M. EEkolohichni problemy stiykoho rozvytku ta blahoustroyu mis'kykh terytoriy ta sposoby yikh vyrishennya //Vestnyk unyversyteta (Hosudarstvennyy unyversytet upravlenyya). 2017. № 2. S. 57-61.

2. BezlyubchenkoO. S. Planuvannya ta blahoustriy mistu: Navchal'nyy posibnyk // O. S. Bezlyubchenko, O. V. Zaval'nyy, T. O. Chernonosova; Khark. nats. akad. mis'k. hosp-va. - KH. : KHNAMH, 2011. $191 \mathrm{~s}$.

3. Berdanova O. V. Planuvannya sotsial'no-ekonomichnoho rozvytku mista: monohrafiya / O. V. Berdanova, V. M. Vakulenko, I. V. Valentyuk [ta in.]; za red. V. M. Vakulenka, M. K. Orlatoho. K., 2011. $160 \mathrm{s.}$

4. Boyko-Boychuk O. V. Svitovi tendentsiyi rozvytku rozvytku mist: mizhnarodnyy dosvid /O. V. Boyko-Boychuk [Elektronnyy resurs]. Rezhym dostupu: http://www.nbuv.gov.ua/e-journals/Dutp/2007-2.

5. Hrechanovs'ka I. H. Mis'ki terytoriyi yak ob'yekt pryrodokorystuvannya / I. H. Hrechanovs'ka // zb. nauk. prats': Ekonomichninauky. Seriya "Rehional'naekonomika". Luts'k, 2008. № 5 (17). CH. 1 s. 279-290.

6. Dovidka pro vykonannya Prohramy ekonomichnoho ta sotsial'noho rozvytku mista Chernihova na 2019 rik za pidsumkamy 1 pivrichchya [Elektronnyy resurs]. Rezhym dostupu: https://chernigiv-rada.gov.ua/sp-uer-esr/ 
7. Dronova O. L. Heourbanistyka: navch. posibnyk. K.: Vydavnychopolihrafichnyy tsentr "Kyyivs'kyy universytet", 2014. $419 \mathrm{~s}$.

8. Ekolohichnyy monitoring $\mathrm{m}$. Chernihiv. Povodzhennya z vidkhodamy [Elektronnyy resurs]. Rezhym dostupu: http://svivem.com.ua/eco1/

9. Zakon Ukrayiny "Pro blahoustriy naseleny khpunktiv" vid 06.09.2005 №2807-IV // Vidomosti Verkhovnoyi Rady Ukrayiny. 2005. № 49, st. 517.

10. Zapotots'kyy S. P. Suspil'no-heohrafichne doslidzhennya ekolohichnoyi povedinki naselennya (naprikladi mist Kyyeva ta Chernihova) S. P. Zapotots'kyy, O. YU. Kononenko, YU. M. Holub // Visnyk Kyyivs'koho natsional'noho universytetu imeni Tarasa Shevchenka. Heohrafiya. 2019. Vyp. 1 (74). S. 48-53.

11. Il'chuk V.P. Kompleksnyy analiz transportnoyi merezhi mista: systemno-analitychnyypidkhid: monohrafiya / V. P. II'chuk, O. I. Panchenko, O. V. Shyshkina, A. V. Tarasenko; Chernih. nats. tekhnol. un-t. Chernihiv: TSNTI, 2014. $869 \mathrm{~s}$

12. Karyy O. I. Prostir mista yak vazhlyvyy chynnyk yoho sotsial'noekonomichnoho rozvytku / O. Karyy // Kommunal'ne hospodarstvo horodiv: nauch.-tekhn. sb. / Khar'kov.nats. akad. misto. khoz-va; otv. red. L. N. Shutenko. Kyev: Tekhnika, 2009. Vyp. 94.

13. Ksenevych M. YA. Mistobudivni osnovy staloho rozvytku mista Kyyeva. K.: Holovkiyivarkhitektura, 2002. $170 \mathrm{~s}$

14. Ofitsiynyy sayt Holovnoho upravlinnya statystyky u Chernihivs'kiy oblasti [Elektronnyy resurs]. Rezhym dostupu: https://www.chernigivstat.gov.ua/ statdani/Demog/dem1 11.htm

15. Ofitsiynyy sayt Hrupy TELE-FONIKA Kable [Elektronnyy resurs]. Rezhym dostupu: https://www.tfkable.com/ru_pl/

16. Ofitsiynyy sayt Kompaniyi "Plast-Boks Ukrayina" [Elektronnyy resurs]. Rezhym dostupu: https://plast-box.com.ua/

17. Ofitsiynyy sayt Osvita.ua [Elektronnyy resurs]. Rezhym dostupu: http://ru.osvita.ua/

18. Ofitsiynyy sayt Proektu USAID "Munitsypal'na enerhetychna reforma v Ukrayini" [Elektronnyy resurs]. Rezhym dostupu: http://www.merp.org.ua/

19. Ofitsiynyy sayt Upravlinnya osvitoyu Chernihivs'koyi mis'koyi rady [Elektronnyy resurs]. Rezhym dostupu: http://osvita.ch.ua/

20. Ofitsiynyy sayt Chernihivs'koho mis'koho portalu [Elektronnyy resurs]. Rezhym dostupu: https://www.gorod.cn.ua/

21. Posats'kyy B.S. Osnovy urbanistyky. Terytorial'ne ta prostorove planuvannya [Tekst]: navch. posibnyk / B. S. Posats'kyy; Nats.un-t "L'viv. politekhnika". 2-he vyd., Dopov. L. :Vyd-voL'viv. politekhniky, 2011. 366 s.

22. Pro zatverdzhennya Pravovoho chlena mis'koho pasazhyrs'koho avtomobil'noho transportu u m. Chernihovi [Elektronnyy resurs]. Rezhym dostupu: https://chernigiv-rada gov.ua/poekty-rishen-vikonkomu/sid-30/id-14197/

23. Pro okhoronu kul'turnoyi spadshchyny: Zakon Ukrayiny vid 08.06.2000 // Vidomosti Verkhovnoyi Rady Ukrayiny. 2000. № 39. st. 333.

24. Pro transportnu merezhu Chernihova [Elektronnyy resurs]. Rezhym dostupu: https://chernigiv-rada.gov.ua/transport-mista/

25. Prohrama povodzhennya $z$ tverdymy pobutovymy vidkhodamy [Elektronnyy resurs]. zatverdzheno Postanovoyu Kabinetu Ministriv Ukrayiny vid 4 bereznya 2004 r. № 265 . Rezhym dostupu: https://www.kmu.gov.ua/ npas/5150488

26. Serebrovskyy F. L. Aératsiya zhyloy zastroyky / F. L. Serebrovskyy. M.: Stroyyzdat, 1971. $112 \mathrm{~s}$

27. Sosnova N. S. Transformatsiya mis'koho seredovyshcha yak vidobrazhennya ekonomichnykh ta suspil'nykh protsesiv u naybil'shykh mistakh Ukrayiny // Dosvid ta perspektyvy rozvytku mist Ukrayiny ta inshykh krayin. Problemy rozvytku naykrupnishykh mist Ukrayiny: zbirnyk naukovykh prats' / vidp. red. YU. M. Palekha. Vyp. 20. K.: In-t "DIPROMISTO", 2011. S. 98-106.

28. Stan dovkillya Chernihivs'koyi oblasti: informatsiyno-analitychnyy ohlyad. Departament ekolohiyi ta pryrodnykh resursiv Chernihivs'koyi ODA [Elektronnyy resurs]. Rezhym dostupu: http://eco.cg.gov.ua/index.php?id= 16808\&tp $=1 \&$ pg

29. Stratehiya rozvytku mista Chernihova do 2020 roku: Rishennya mis'koyi rady vid 29 hrudnya 2016 roku. Chernihiv: Chernihivs'ka mis'ka rada. [Elektronnyy resurs]. Rezhym dostupu: http://www.chernigiv-rada.gov.ua/ filesstatic/rozvitok/Strategiya\%202020_12-05-2017_10-31.pdf

30. Uhryumova A. A. Komfortnist' yak faktor stiykoho rozvytku mis'koho seredovyshcha / A. A. Uhryumova, L. E. Pautova, E. P. Pautova // Rosiya: tendentsiyi ta perspektyvy rozvytku. Ezhehodnyk. M.: YNYON RAN, 2018. Vypusk 13. Chast' 2. S. 245-251.

31. Berry B. Cities as systems within systems of cities / B. Berry // Papers in regional Science. 1964. V. 13. Iss. 1. P. 147-163.

32. Chang T. Y., Lai Y. A., Hsieh H. H. et al. Effects of environmental noise exposure on ambulatory blood pressure in young adults. Environ Res 2009. Vol. 109. P. 900-905.

33. Harris C. D. The nature of cities / C. D. Harris, E. L. Ullman // Annals of the American Academy of Political and Social Science. 1945. № 242. P. 7-17.

34. Jensen-Butler $C$. Competition between cities, urban performance and the role of urban policy: a theoretical framework / Edited by C. JensenButler, A. Shachar, J. van Weesep // European cities in competition. Avebury : European science foundation, 1997. P. 3-42.

35. Lusk S. L., Gillespie B., Hagerty B. M., Ziemba R. A. Acute effects noise on blood pressure and heart rate // Arch Environ Health. 2004 Vol. 59. P. 392-329.
36. Park R. The City as a Social Laboratory / Robert E. Park: On Social Control and Collective Behavior // Selected Papers, Ed and with introduction by Ralph H. Turner. Chicago ; London, 1967. P. 3-18.

37. Taylor P. J. Cities in Globalization: Practices, Policies and Theories I P. J. Taylor, B. Derudder, P. Saey, F. Witlox (eds.). London, 2007.

\section{Список використаних джерел}

1. Аль-Фахад А. З. М. Экологические проблемы устойчивого развития и благоустройства городских территорий и способы их решения // Вестн. университета (Гос. университет управления). 2017. № 2. С. 57-61.

2. Безлюбченко О. С. Планування та благоустрій міст : навч. посіб. / О. С. Безлюбченко, О. В. Завальний, Т. О. Черноносова; Харків. нац. акад. міськ. госп-ва. - Х. : ХНАМГ, 2011. - 191 с.

3. Берданова О. В. Планування соціально-економічного розвитку міста: монографрія / О. В. Берданова, В. М. Вакуленко, І. В. Валентюк та ін.; за ред. В. М. Вакуленка, М. К. Орлатого. - К., 2011. - 160 с.

4. Бойко-Бойчук О. В. Світові тенденції розвитку міст: міжнародний досвід / О. В. Бойко-Бойчук [Електронний ресурс]. - Режим доступу : http://www.nbuv.gov.ua/e-journals/Dutp/2007-2

5. Гречановська I.Г. Міські території як об'єкт природокористування / І. Г. Гречановська : зб. наук. пр. : Економічні науки. Серія "Регіональна економіка". - Луцьк, 2008. - № 5(17). - Ч. 1 - С. 279-290.

6. Довідка про виконання Програми економічного і соціального розвитку міста Чернігова на 2019 рік за підсумками 1 півріччя [Електронний pecypc]. - Режим доступу: https://chernigiv-rada.gov.ua/sp-uer-esr/

7. Дронова О. Л. Геоурбаністика: навч. посіб. / О. Л. Дронова. - К.: ВПЦ "Київськийуніверситет", 2014. - 419 с.

8. Екологічний моніторинг м. Чернігів. Поводження з відходами [Електронний ресурс] - Режим доступу: http://svivem.com.ua/eco1/

9. Про благоустрій населених пунктів: Закон України від 06.09.2005 №2807-IV // Відомості Верховної Ради України. - 2005. № 49 , ст. 517 .

10. Запотоцький С. П. Суспільно-географічне дослідження екологічної поведінки населення (на прикладі міст Києва та Чернігова) / С. П. Запотоцький, О. Ю. Кононенко, Ю. М. Голуб // Вісн. Київ. ун-ту. Географія. - 2019. - Вип. 1 (74). - С. 48-53

11. Комплексний аналіз транспортної мережі міста: системноаналітичнийпідхід: моногр. / В.П.Ільчук, О.І.Панченко, О.В.Шишкіна, А. В. Тарасенко ; Черніг. нац. технол. ун-т. - Чернігів : ЦНТІ, 2014. - 869 с

12. Карий О. І. Простір міста як важливий чинник його соціальноекономічного розвитку / О. Карий // Коммунальное хозяйство городов науч.-техн. сб. / Харьков. нац акад. город. хоз-ва ; отв. ред. Л. Н. Шутенко. - Киев: Техніка, 2009. - Вып. 94.

13. Ксеневич М.Я. Містобудівні основи сталого розвитку міста Києва - К.: Головкиївархітектура, 2002. - 170 с.

14. Офіційний сайт Головного управління статистики у Чернігівській області [Електронний ресурс]. - Режим доступу: https://www.chernigivstat.gov.ua/statdani/Demog/dem1_11.htm

15. Офріційний сайт Групи TELE-FONIKAKable [Електронний ресурс]. - Режим доступу: https://www.tfkable.com/ru_pl/

16. Офіційний сайт Компанії "Пласт-Бокс Україна" [Електронний ресурс]. - Режим доступу: https://plast-box.com.ua/

17. Офріційний сайт Освіта.иа [Електронний ресурс]. - Режим доступу: http://ru.osvita.ua/

18. Офіційний сайт Проекту USAID "Муніципальна енергетична реформа в Україні" [Електронний ресурс] - Режим доступу: http://www.merp.org.ua/

19. Офріційний сайт "Управління освіти Чернігівської міської ради" [Електронний ресурс]. - Режим доступу: http://osvita.ch.ua/

20. Офіційний сайт "Чернігівський міський портал" [Електронний ресурс]. - Режим доступу: https://www.gorod.cn.ua/

21. Посацький Б. С. Основи урбаністики. Територіальне і просторове планування : навч. посіб. / Б. С. Посацький ; Нац. ун-т "Львів. політехніка". - 2-ге вид., доп. - Л. : Вид-во Львів. політехніки, 2011. - 366 с.

22. Про затвердження Правил користування міським пасажирським автомобільним транспортом у м. Чернігові [Електронний ресурс]. Режим доступу: https://chernigiv-rada.gov.ua/poekty-rishen-vikonkomu/ sid-30/id-14197/

23. Про охорону культурної спадщини: Закон України від 08.06.2000 // Відомості Верховної Ради України. - 2000. - № 39. - ст. 333.

24. Про транспортну мережу Чернігова [Електронний ресурс]. - Peжим доступу: https://chernigiv-rada.gov.ua/transport-mista/

25. Програма поводження з твердими побутовими відходами [Електронний ресурс] // Затверджено Постановою Кабінету Міністрів України від 4 березня 2004 р. № 265. - Режим доступу: https://www.kmu.gov.ua/ npas/5150488

26. Серебровский Ф. Л. Аэрация жилой застройки / Ф. Л. Серебровский. - М.: Стройиздат, 1971. - 112 с.

27. Соснова Н. С. Трансформація міського середовища як відображення економічних і суспільних процесів у найбільших містах України // Досвід та перспективи розвитку міст України та інших країн. Проблеми розвитку найкрупніших містУкраїни : зб. наук. пр. / відп. ред. Ю. М. Папеха. - К. : Ін-т "ДІПРОМІСТО", 2011. - Вип. 20. - С. 98-106.

28. Стан довкілля Чернігівської області: інформаційно-аналітичний огляд. - Департамент екології і природних ресурсів Чернігівської ОДА 
[Електронний ресурс]. - Режим доступу: http://eco.cg.gov.ua/index.php?id=16808\&tp=1\&pg

29. Стратегія розвитку міста Чернігова до 2020 року: Рішення міської ради від 29 грудня 2016 року. - Чернігів: Чернігівська міська рада. [Електронний ресурс]. - Режим доступу: http://www.chernigiv-rada.gov.ua/ filesstatic/rozvitok/Strategiya\%202020 12-05-2017 10-31.pdf

30. Угрюмова А. А. Комфортность как фактор устойчивого развития городской среды / А. А. Угрюмова, Л. Е. Паутова, Е. П. Паутова // Россия: тенденции и перспективы развития. Ежегодник. - М. ИНИОН РАН, 2018. - Вып. 13. - 4. 2 - С. 245-251.

31. Berry B. Cities as systems within systems of cities / B. Berry // Papers in regional Science. - 1964. - V. 13. - Iss. 1. - P. 147-163.

32. Effects of environmental noise exposure on ambulatory blood pressure in young adults / T. Y. Chang, Y. A. Lai, H. H. Hsieh et al. // Environ Res. - 2009. - Vol. 109. - P. 900-905.
33. Harris C. D. The nature of cities / C. D. Harris, E. L. Ullman // Annals of the American Academy of Political and Social Science. - 1945 - № 242. - P. 7-17.

34. Jensen-Butler $C$. Competition between cities, urban performance and the role of urban policy: a theoretical framework / Edited by $C$.JensenButler, A. Shachar, J. van Weesep // European cities in competition. - Avebury : European science foundation, 1997. - P. 3-42.

35. Acute effects of noise on blood pressure and heart rate / S. L. Lusk, B. Gillespie, B. M. Hagerty, R. A. Ziemba // Arch Environ Health. - 2004. Vol. 59. - P. 392-329.

36. Park R. The City as a Social Laboratory / Robert E. Park: On Social Control and Collective Behavior // Selected Papers, Ed. and with introduction by Ralph H. Turner. - Chicago ; London, 1967. - P. 3-18.

37. Taylor P. J. Cities in Globalization: Practices, Policies and Theories I P. J. Taylor, B. Derudder, P. Saey, F. Witlox (eds.). - London, 2007.

Надійшла до редколегії 30.09.20

С. Запотоцький, д-р геогр. наук, проф.,

В. Запотоцька, канд. геогр. наук, асист.,

Ю. Голуб, асп.

Київський національний університет імені Тараса Шевченка, Київ, Україна

\section{СОЦІАЛЬНО-ЕКОЛОГІЧНІ АСПЕКТИ}

\section{ЗАБЕЗПЕЧЕННЯ БЛАГОУСТРОЮ М. ЧЕРНІГОВА}

Розкрито основні риси благоустрою міської території. Охарактеризовано його завдання та головні елементи. Проаналізовано ситуацію, яка пов'язана зі станом забруднення атмосферного повітря, водних ресурсів, у т. ч. у м. Чернігові. Описано основні джерела забруднення довкілля. Розглянуто проблему поводження із твердими побутовими відходами в місті. Здійснено характеристику міського шуму як фактора забруднення атмосфери, який негативно впливає на здоров'я людини. Охарактеризовано дію інсоляції в межах міста, вказано наслідки й вимоги щодо її врахування при плануванні міст, районів чи кварталів. Проведено аналіз аераційного режиму міської території як чинника, що впливає на комфортність проживання у місті. Визначено роль зелених насаджень, що є важливим елементом природного середовища та благоустрою міського простору. Описано три типи комфортності у місті (екологічна, соціальна та урбаністична) та вказано на їхні основні риси. Запропоновано наше бачення комфортного міста, яке має бути компактним, зручним і поліцентричним, забезпечувати рівний доступ до благ різним верствам суспільства. Охарактеризовано промисловий комплекс та причини зниження темпів і обсягів промислового виробництва у деяких раніше провідних галузях. Визначено основні підприємства м. Чернігова, які впроваджують сучасні технологічні рішення. Розглянуто транспортний комплекс міста і тенденції його подальшого розвитку. Проведено аналіз закладів охорони здоров'я, освіти, культури й відпочинку, а також ситуації, яка склалася в соціальній сфері Чернігова. Здійснено аналіз соціологічного опитування серед жителів міста щодо проблем благоустрою, які найбільше турбують мешканців. Це дослідження засвідчило, що найактуальнішими для містян є питання вивезення сміття та поводження 3 побутовими відходами, проблема теплопостачання і робота громадського транспорту. Аналіз відповідей респондентів виявив, що вони підтримують позитивні тенденції у створенні нових спортивних і дитячих майданчиків, проте хочуть, щоб ці об'єкти знаходились у пішій доступності від місця їхнього проживання. Більшість містян задоволена роботою міської влади щодо вирішення питань благоустрою та комфортності Чернігова, сподіваються на подальші позитивні зрушення. Визначено пріоритетні напрями розвитку м. Чернігова на найближчі роки. Серед них: підвищення рівня життя населення, покращення стану навколишнього природного середовища, подальше економічне зростання, підвищення зайнятості населення міста, оновлення та створення нової якісної інфраструктури, підтримка малого і середнього бізнесу.

Ключові слова: місто, благоустрій міської території, комфортність, соціально-екологічний стан, промисловий комплекс, розвиток міста.

С. Запотоцкий, д- геогр. наук, проф.,

В. Запотоцкая, канд. геогр. наук, асист.,

Ю. Голуб, асп.

Киевский национальный университет имени Тараса Шевченко, Киев, Украина

\section{СОЦИАЛЬНО-ЭКОЛОГИЧЕСКИЕ АСПЕКТЫ ОБЕСПЕЧЕНИЯ БЛАГОУСТРОЙСТВА Г. ЧЕРНИГОВА}

Раскрыты основные черты благоустройства городской территории. Охарактеризованы его задачи и главные элементы. Проанализирована ситуация, связанная с состоянием загрязнения атмосферного воздуха, водных ресурсов, в $m$. ч. 6 г. Чернигове. Описаны основные источники заерязнения окружающей среды. Рассмотрена проблема обращения с твердыми бытовыми отходами в городе. Осуществлено характеристику городского шума как фактора загрязнения атмосферы, который негативно влияет на здоровье человека. Охарактеризовано действие инсоляции в пределах города, указано последствия и требования касательно ее учета при планировании городов, районов или кварталов. Проведен анализ аэрационного режима городской территории как фактора, влияющего на комфортность проживания в городе. Определена роль зеленых насаждений, которые являются важным элементом природной среды и благоустройства городского пространства. Описаны три типа комфортности в городе (экологическая, социальная и урбанистическая) и указано на их основные черты. Предложено наше видение комфортного города, который должен быть компактным, удобным и полицентричным, обеспечивать равный доступ к благам разным слоям общества. Охарактеризован промышленный комплекс и причины снижения темпов и объемов промышленного производства в некоторых ранее ведущих отраслях. Определены основные предприятия г. Чернигова, которые внедряют современные технологические решения. Рассмотрен транспортный комплекс города и тенденции его дальнейшего развития. Проведен анализ учреждений здравоохранения, образования, культуры и отдыха, а также ситуации, сложившейся в социальной сфере Чернигова. Осуществлен анализ социологического опроса среди жителей города по проблемам благоустройства, которые больше всего беспокоят жителей. Данное исследование показало, что наиболее актуальными для горожан вопросами являются: вывоз мусора и обращения с бытовыми отходами, проблема теплоснабжения и работа общественного транспорта. Анализ ответов респондентов показал, что они поддерживают положительные тенденции в создание новых спортивных и детских площадок, однако хотят, чтобы данные объекты находились в пешей доступности от места их проживания. Большинство горожан довольн работой городских властей по решению вопросов благоустройства и комфортности Чернигова, надеются на дальнейшие положительные сдвиги. В работе определены приоритетные направления развития г. Чернигова на ближайшие годы. Среди них: повышение уровня жизни населения, улучшение состояния окружающей среды, дальнейший экономический рост, повышение занятости населения города, обновления и создания новой качественной инфраструктуры, поддержка малого и среднего бизнеса.

Ключевые слова: город, благоустройство городской территории, комфортность, социально-экологическое состояние, промышленный комплекс, развитие города. 